\title{
Learning Loss: A Real Threat in Education for Underprivileged Students and Remote Regions during the Covid-19 Pandemic
}

\author{
Anju Nofarof Hasudungan \\ Senior High School 1 Rupat, Indonesia, \\ anjuhasudungan81@guru.sma.belajar.id \\ Ofianto \\ Universitas Negeri Padang, Indonesia \\ ofianto@fis.unp.ac.id \\ Tri Zahra Ningsih \\ Trizahra10019@gmail.com
}

\begin{abstract}
This study aims to describe the real threat of learning loss for underprivileged students and remote areas, due to school closures and distance learning in Riau Province, Indonesia. On the other hand, keeping students safe from the dangers of the COVID-19 virus is the main factor. Distance learning is a solution to this dilemma, but it is very difficult for underprivileged students and remote regions to implement, because: 1) Students have never used various educational technology platforms in distance learning 2) Do not have a smartphone and mobile data plans 3) Internet signal in remote areas is not good for distance learning. The results of this study describe, when distance learning was first implemented, as many as $75 \%$ of 206 underprivileged students and ten schools experienced difficulties when using educational technology platforms for distance learning. However, after two years, there has been an increase in the participation of underprivileged students in distance learning. In addition, it has become a habit, subsidized mobile data plans from the government, adaptive curricula and variations in learning methods when distance learning, have become important factor in increasing the participation of underprivileged students and remote regions.
\end{abstract}

Keywords: Learning Loss, Underprivileged Students, Remote Regions, COVID-19, Distance Learning

\section{Introduction}

The COVID-19 pandemic has an impact on all aspects of human life, including the education aspect. The real impact that occurs and is felt is the change in the pattern of the teaching-learning process from face-to-face to distance learning. The issuance of the Circular Letter of the Minister of Education and Culture Number 4 of 2020 concerning the Implementation of Education Policies in the Emergency Period for the Spread of COVID-19, since March 2020 the learning process by distance learning has begun to be carried out by schools. However, in general, the 2020/2021 school year in the first semester of distance learning is massively implemented in Indonesia. Senior High School 1 Rupat, Bengkalis Regency, Riau Province began to carry out distance learning from home from March 30 to April 242020 using three applications, namely, google classroom, WhatsApp group and zoom meeting. Primasari \& Zulela (2021) explain that the distance learning system does not require students or are required to come to school to carry out learning. Many tools are ultimately applied by teachers to implement distance learning. The distance learning facilities cannot be avoided from the 
development of information and communication technology. The learning facilities include the zoom application, google classroom, google meet, YouTube, television, and WhatsApp. The COVID-19 pandemic has given us the opportunity to pave the way for the introduction of digital learning (Pokhrel \& Chhetri, 2021). Distance learning is considered to be in line with the vision and mission of future learning in the era of the industrial revolution 4.0 and the era of society 5.0 (Abidah et al., 2020).

Minister of Education, Culture, Research, and Technology, Nadiem Anwar Makarim explained, there are problems such as unreliable connectivity, the problem of not having a device, these are fundamental problems so that the implementation of distance learning in various regions is very difficult (Direktorat Guru dan Tenaga Kependidikan Pendidikan Dasar Kemendikbud Ristek, 2021). Day et al., (2021) describe that the Global South countries do not have adequate digital infrastructure, there is a digital divide that occurs between developed and developing countries. Distance learning will take place effectively if it is supported by a good internet network, teachers and students understand using various applications for distance learning and the availability of smartphones and internet quotas. On the other hand, students whose parents have low education and live in remote areas tend to spend time playing and have unclear learning times (Alifia et al., 2020).

The diversity of parents' abilities and parents' socioeconomic conditions also affect student learning at home (Purnamasari et al., 2021). Thus, parents and families become factors that affect students' daily activities, especially learning. Students who live in urban areas and have highly educated parents generally have a more balanced division of time between learning and playing activities, especially during distance learning. The role of parents is very important in ensuring students use of smart phones for distance learning. There is also the issue of unstable emotional psychology of students, because they have not seen friends and teachers at school for a long time (isolation activity). Students' psychological disturbances can affect academic quality (Hakami et al., 2021). Aswat et al., (2021) stated that distance learning has an effect on students' interest in learning, because distance learning is different from classroom learning. Likewise with the development of emotional intelligence of students who experience changes in sources of inspiration and objects that become sources of imitation of students in managing their attitudes. Students also experience a decrease in motivation because they have to study at home not with their peers as they do at school (Putra et al., 2020). Students are not mature enough to be able to respond to this pandemic condition, especially to be able to learn independently. Likewise, parents who are overwhelmed in guiding their children to continue to be disciplined in distance learning. Due to this pandemic and distance learning, parents are aware of the important role of a teacher in educating the nation's children.

Hares \& Mundy (2020)estimates that $91.3 \%$ or 1.57 billion students drop out of school worldwide due to the COVID-19 pandemic. In addition to lost learning time, it is estimated that between 7 and 9.7 million children will drop out of school due to the economic impact of the pandemic (Wagner \& Warren, 2020). In another estimate, students can experience learning loss more than one year after three months of school closures because they fall further behind when schools reopen (Kaffenberger, 2021). Chen et al., (2021) explain that students have paid a high price in learning loss, even the impact can be detrimental to the economic well-being of some students throughout their lives. Hanushek \& Woessmann(2020) published by the Organization for Economic Co-operation and Development (OECD) revealed that there is no doubt that school closures in the first half of 2020 have resulted in significant learning loss for the underprivileged student group. Some school reopening strategies that are implemented will only exacerbate the 
learning losses that have already occurred. This disadvantage will follow the student into the labor market. Students as well as the state, they tend to experience adverse economic outcomes. Being absent from school for a long time is likely to have a major impact on student achievement (Kuhfeld et al., 2020).

Golden Indonesia in 2045 will only happen if the government is able to take advantage of the potential of the demographic bonus, namely by preparing quality Indonesian human resources. Quality human resources can only be formed through the educational process (Hasudungan \& Kurniawan, 2018). Global school closures present what international organizations call an "unprecedented risk to the education, protection and well-being of students". Underprivileged students and remote areas cannot optimally implement distance learning, due to financial constraints to purchase mobile data plans, inadequate internet network, and lack of understanding in using technology for distance learning. In addition, the intensity of parental participation during distance learning is low because of their educational background and working hours. This condition is also exacerbated by the absence of teachers. This is a warning to the government, that in fact it is not only learning loss that occurs but the low quality of the country's Human Resources in the future.

Based on the discussion above, this study aims to describe learning loss as a real threat in education to underprivileged students and remote areas.

\section{Research Method}

This research uses descriptive qualitative research method. Creswell (2018) explains that qualitative research is a type of research that can describe phenomena that occur factually. Data were collected through questionnaires using google forms and in collaboration with teachers in each school. Specifically for students from Senior High School 1 Rupat, the researchers also collected data through a history test and observation. Questionnaire questions related to distance learning such as, what difficulties did students find when they first implemented distance learning, do they still have difficulties in implementing distance learning, what makes students today no longer have difficulty implementing distance learning, the type of work parents do, and whether to receive education funding from scholarships. There are 230 students participating from twelve schools, but considering the focus of this research is from underprivileged students and schools in remote areas. So, the researcher selects and separates valid and invalid data. Finally, the subjects of this study were 206 underprivileged students from ten senior high schools located in remote areas of Riau Province of Indonesia. The data obtained from the results of tests, questionnaires and observations were analyzed with the stages of data reduction, data presentation and conclusion drawing. The triangulation technique used to ensure the validity of the data (Kurniawan \& Budiyono, 2021; Hasudungan, 2021). The data analysis technique used is an interactive model consisting of four components of the analysis process, namely, data collection, data reduction, data presentation and drawing conclusions (Miles \& Huberman, 1994). Data analysis is carried out by organizing the data obtained into a category, breaking down the data into units, analyzing important data, compiling or presenting data, that is in accordance with the research problem in the form of reports and making conclusions so that they are easy to understand. 


\section{Results and Discussion}

\subsection{Educational problems before and during the COVID-19 pandemic}

In fact, prior to the pandemic, the biggest problem with Indonesian education was the unequal quality of education, even though the Indonesian education system had achieved remarkable success in the short time since independence in 1945. The challenge of providing access to primary schools across this large archipelago has been largely met. Indonesians are largely literate, numerate, speak the same national language, and share a common sense of national identity across their 13,000 islands (Heyward \& Sopantini, 2013). Given that Indonesia's digital education infrastructure is still below the level of developed countries and not evenly distributed, and the unpreparedness of teachers and students due to changing learning patterns, many students and teachers from remote areas have difficulty implementing distance learning. The COVID-19 pandemic has had an impact on the education sector. For example, based on the Circular of the Minister of Education and Culture of March 24, 2020. The circular regulates, among other things, that face-to-face learning in class is replaced by Distance Learning, national exams are abolished, there is leeway in completing curriculum achievements for grade promotion and graduation.

Beatty et al., (2021) found a large gap between students' abilities and the standards set by the national curriculum, that learning declined over the course of 14 years. The average 7 th grader in 2014 achieved the same numerical mastery as the 4th grader's average in 2000. The learning decline was widespread, affecting all subgroups. Middle and high school enrollment increased during this time period, but this decline was not due to changes in student composition. This means that learning loss has occurred before the COVID-19 pandemic. In the Philippines as a developing country in Southeast Asia like Indonesia, there is a scenario where there is a $30 \%$ learning loss impact for 3rd grade Maranao-speaking students and this is equivalent to a school closure of around 3 months (Cummiskey et al., 2020). Losses are greater in math than reading, and underprivileged students regress more severely in all subjects (Chen et al., 2021). Learning loss is not only in reading and mathematics. Although reports of learning loss typically focus on these two areas, students have experienced learning loss in all aspects of learning and students as whole people. These disadvantages include areas that are much more important than reading and mathematics, such as emotional social well-being, attitudes toward learning, interaction with friends, and physical and psychological development (Zhao, 2021). The World Bank estimates that around $\$ 10$ trillion in income could be lost to the current cohort of students, due to lower learning rates and their potential for dropping out (Azevedo et al., 2021).

Distance learning has also contributed to increasing dropout rates and early marriage. The findings of the Indonesian Child Protection Commission (KPAI), that there are 119 students who are married, male and female, ranging in age from 15-18 years and students who drop out of school from the provinces in Java, West Nusa Tenggara and Bengkulu (Mabruroh, 2021). Overall, all of this has the potential to cause the lost generation, a condition that is more dangerous than learning loss. The Indonesian government and all existing stakeholders, if they do not find solutions to minimize these problems, it will be impossible to take advantage of the 2030 demographic bonus to realize a golden Indonesia in 2045.

Therefore, the education sector is among the most vulnerable, being affected by the COVID-19 pandemic (Djalante et al., 2020). Sparrow et al.,(2020) explained, the education sector is quite prepared for extended school closures and distance learning. However, there is no strategy to address the accumulated learning losses resulting from this crisis. Research results 
from Gershenson \& Hayes (2017), outlines the well-documented loss of summer learning of lowincome students in reading appears to be entirely driven by lower summer learning rates. However, there was no such difference in mathematical achievement. The low level of learning and the effect on learning loss not only occurred during the COVID-19 pandemic but before the pandemic. Sabates et al., (2021) revealed the results of their research in Ghana, which is also a developing country, has shown an average learning loss of $66 \%$ of the previous learning gain in basic arithmetic during the transition period. More importantly, it is estimated that the widening gap in learning loss corresponds to a lack of home learning support, as well as a lack of home learning resources.

\subsection{The problem of underprivileged students and schools in remote areas when implementing distance learning}

Countries around the world have responded with various measures to reduce the potential for learning loss due to school closures: about 40 percent of countries extend the academic year and the same proportion of countries prioritize certain curriculum areas. However, more than half of the 142 countries that responded to the survey reported that no curriculum adjustments have been or will be made (UNESCO et al., 2021). Indonesia is one of the countries that make curriculum adjustments during the COVID-19 pandemic. The Government of Indonesia through Presidential Decree of the Republic of Indonesia Number 12 of 2020 concerning Determination of Non-Natural Disasters, namely, the spread of COVID-19 as a national disaster. Based on the presidential decree and efforts to make curriculum adjustments, on August 7, 2020, Decree of the Minister of Education and Culture of the Republic of Indonesia Number 719/P of 2020 was issued, which contains Guidelines for Curriculum Implementation in Education Units in Special Conditions. The decision instructs schools to use a curriculum that is in accordance with the learning needs of students and teachers to analyze the Essential Basic Competencies on the syllabus for all subjects. The decision from the government should be appreciated, because it has issued regulations that are very contextual with the conditions of the COVID-19 pandemic. However, in the implementation of distance learning, various problems were found that had an impact on the inability to minimize learning loss for underprivileged students and remote areas.

Figure 1: Underprivileged students' answer results

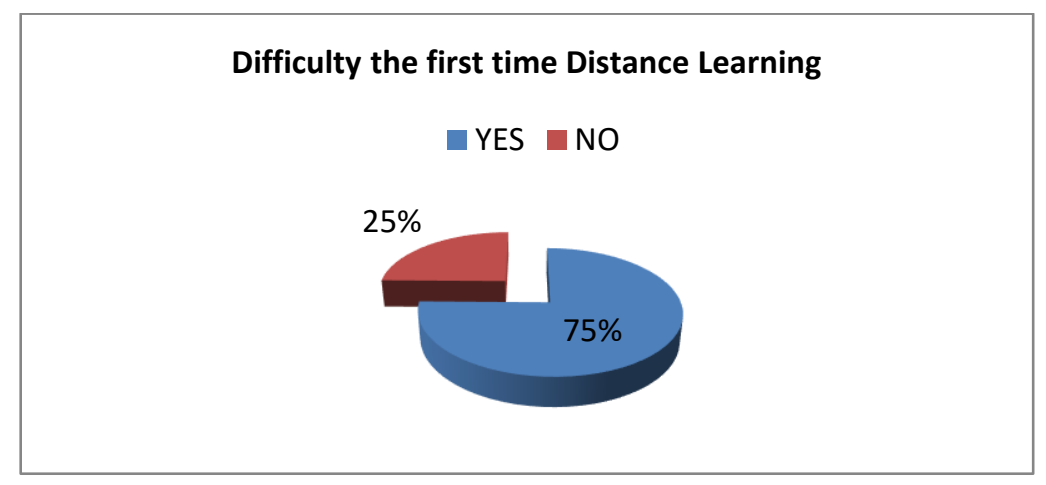

Figure 1 above provides information, when distance learning was first implemented, as many as $75 \%$ of 206 underprivileged students and ten schools experienced difficulties when using educational technology platforms for distance learning. 
Figure 2.Underprivileged students answer after two years of distance learning

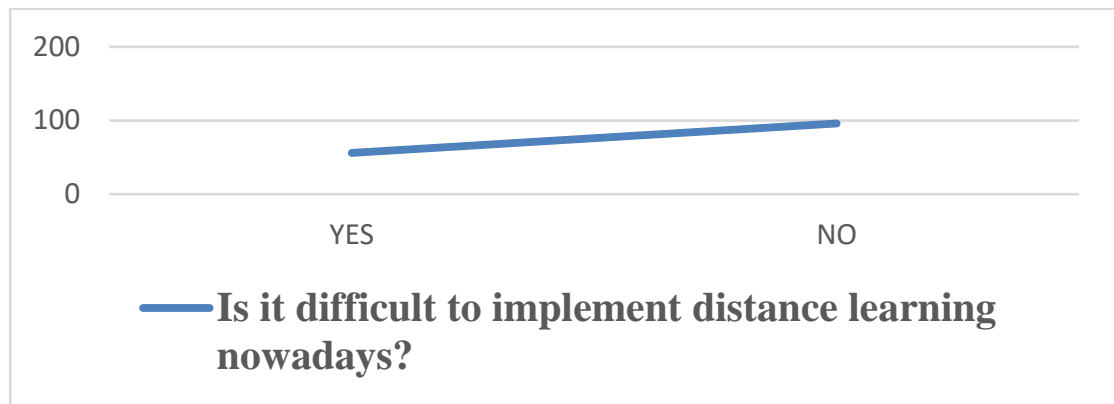

Figure 2 provides information, first time they started distance learning, there were 155 underprivileged students who had difficulty implementing distance learning, currently only 59 students are still having difficulties. In addition, it has become a habit, subsidized mobile data plans from the government, adaptive curricula and variations in learning methods when distance learning, have become important factors in increasing the participation of underprivileged students and remote regions.

Underprivileged students are most affected by the pandemic in the education sector. Yarrow et al., (2020) projections published by the World Bank on 2018 PISA data, for example, found that the Program for International Student Assessment (PISA) score decreased in the reading aspect of the poorest group by $4 \%$, compared to the richest group, which fell $2 \%$. The PISA score gap between the two groups before the pandemic was 57 points, after the pandemic it was 64 points. Muttaqin et al., (2017) describe that the higher the poverty rate and per capita public education expenditure, the higher the probability of children dropping out of school. Inequality is also expected to increase during and after the pandemic, especially for groups that are already vulnerable and marginalized (Yarrow et al., 2020). During the COVID-19 pandemic, there has been a decline in economic growth in various countries in the world, including Indonesia. As a result, many parents of students are no longer working because the place where they work is not able to provide wages. That's why the Indonesian government avoided a very disturbing total lockdown, a dilemma between staying healthy and the economy (Chowdhury \& Jomo, 2020).

Study results from Mata Garuda Institute on the effectiveness of mobile data plans subsidies were presented in a Webinar entitled education dialogue: The Effectiveness of Internet Quota Assistance Distributed "on November 8, 2020 through a zoom meeting. The finding is that underprivileged students who do not have smart phones have difficulty accessing the government subsidy. Meanwhile, they need a smart phone to participate in distance learning. However, despite the many shortcomings, this policy deserves appreciation, at least the government has spent IDR 7.2 Trillion to fulfill the aspirations for the subsidy of mobile data plans (Abdi, 2020; Kasih, 2020).

Learning loss on a large scale and long term will have an impact on the inability to take advantage of the demographic bonus so that Indonesia's golden generation in 2045 will fail to materialize, this situation can be called the lost generation. In the short term, it will widen the gap in the quality of students from urban and remote areas, between students from rich and underprivileged families, and decrease learning achievement. 


\subsection{Stakeholder collaboration: minimize learning loss}

The chairman of the Executive Board of the Indonesian Teachers' Association, Dudung Nurullah Koswara, said that the impact of learning loss could be reduced by increasing the synergy of education stakeholders namely, the synergy between parents, teachers, the community, and the students themselves (Widyanuratikah, 2021). Collaboration is also one of the 21 st century competencies. Problems that occur in the current environment, can no longer be solved individually, especially the COVID-19 pandemic disaster which has not yet been completed, even the latest variations have emerged. Collaboration in Indonesian cultural terms is gotongroyong. A habit that has existed for a long time and is still practiced by many Indonesians. Currently, many Indonesian figures and leaders are campaigning for gotongroyong, so that together they can survive the COVID-19 Pandemic. Surely creative leadership is able to balance the disruption caused by the virus (Boudreau, 2020). Both developing and developed countries have been devastated by the COVID-19 pandemic. Even hundreds of millions of people lost their lives and millions of students experienced learning loss.

\subsection{Government and schools: what can be done to minimize learning loss?}

The government and schools can minimize learning loss with the following roles; 1) Optimizing teaching and learning supports and resources during school closures) such as the Rumah Belajar Portal owned by the Ministry of Education, Culture, Research, and Technology 2) Train teachers in mastering the blended learning method, namely, synchronous and asynchronous learning 3) Provide targeted mobile data plans subsidies 4) Rebudgeting in the use of the School Operational Assistance Fund Program (BOS). More affirmative education policies from the central and local governments are highly expected by remote communities (Muslim, 2021). Regarding the provision of mobile data plans subsidies for students, teachers and lecturers. The government's good intentions to ease the burden on students through this policy should be appreciated. However, the government needs to look again, who is the real target of this policy, if all teachers and students, then it must be ensured that students who need the most such as underprivileged students do not have smart phones and remote areas that do not have adequate internet access in implementing distance learning.

United Nations (2020) suggests, short-term measures to support children's sustainable access to education, for example, through better internet access and accelerated efforts to develop online educational materials. Areas with blank spots are provided with Base Transceiver Station (BTS) assistance so that distance learning can take place smoothly, students still have regularity in learning. Underprivileged students are the ones who do not get subsidized mobile data plans, because even smartphones are not available. If the government wants mobile data plans subsidy policy to be right on target, it can use the Social Welfare Integrated Data (DTKS) from the Ministry of Social Affairs as the basis for providing mobile data plans subsidies to underprivileged students. However, it is also hoped that it will not only subsidize mobile data plans, but also provide assistance in providing communication devices (smartphones).

\subsection{Teacher: what can be done to minimize learning loss?}

Dedicated teachers with high levels of self-efficacy, cultural competence and able to identify students well, because ethnicity, language, education, and poverty similarities can create a pleasant learning environment (Banerjee, 2016). Williams et al., (2019) presented their findings, that high school students' perspectives on how schools can promote academic success in students living in poverty are presented in three main themes: 1) Create a culture of hope 2) Develop a relational network and 3) Build meaningful parent-school collaboration. 
The efforts of teachers as the frontline in minimizing learning loss, researcher provide recommendations, as follows: 1) Designing varied learning, according to the abilities, talents and interests of students (Learning Based on Student Needs) 2) Take a good approach, so that students are motivated to be actively involved in distance learning. In short, when students' motivation is good, their learning achievement can also be good. Both intrinsic and extrinsic motivation have been used to explain success or failure to fulfill any task (Yulia, 2013)3) Use another approach if it is indicated that there are students who have limited online communication 4) Coordination and communication between teachers and parents. The digital revolution is undeniable and will have a positive impact on education in Indonesia, if we are able to take advantage of it. The research results of Kisno et al., (2021) show that synchronous or asynchronous learning platforms can reduce teacher time loss through interactive talk shows or webinars and online classes, helping users spend the right time with innovative games. Technology helps solve Indonesia's education problems. Of course, regulations that favor the characteristics of the Indonesian nation.

After The COVID-19 pandemic ends, the use of technology in education will continue to be relevant and used, the world of education is used to it. For almost two years, Indonesia was forced to be able to do distance learning. This can be used as a momentum to improve the quality of learning by utilizing the advantages of using technology in education. According to researchers, the use of technology appropriately and contextually is a must and there is nothing wrong. This pandemic accelerates the acceleration of technology in the world of education. Pedagogy and technology are two important factors in technology-based learning. The positive impact of using technology in education, in addition to preventing students and teachers from meeting face-to-face so as to avoid the transmission of COVID-19. Also, get quality teaching materials, cheap and easy to get. While the negative impact, students have the potential to feel alone and alienated from the surrounding environment, transnational ideologies are vulnerable and not ready for students to consume.

\section{Conclusion}

At the beginning of the first-time distance learning, held in March 2021, underprivileged students and remote areas had difficulty in participating. The reasons are: 1) Students have never used various educational technology platforms in distance learning 2) Do not have a smartphone and mobile data plans 3) Internet signal in remote areas is not good for distance learning. This has an impact on learning loss. Students cannot follow the learning process as they do in schools. The results of the historical knowledge test have decreased drastically, only five students per class are able to reach the predetermined standard. The policy of the Ministry of Education, Culture, Research, and Technology by issuing Ministerial Decree No. 719/P of 2020 which contains Guidelines for Curriculum Implementation in Education Units in Special Conditions has a systemic positive impact. Namely, providing flexibility to schools in using the curriculum according to the needs of students. In essence, there has been a simplification of the curriculum during the COVID-19 pandemic. The policy has an impact on graduation results and grade promotions, which have increased, because the standards are relaxed. Thus, learning mastery increases compared to the period before the pandemic. However, tests carried out without allowances and adjustments, such as PISA, many credible world institutions predict a decrease in scores and learning completeness. Even though the pandemic is over, students will get used to using technology in learning. 


\section{References}

Abdi, A. P. (2020). Tuntutan Mahasiswa saat Corona: Bebaskan UKT atau Subsidi Pulsa. Tirto.Id. https://tirto.id/tuntutan-mahasiswa-saat-corona-bebaskan-ukt-atau-subsidi-pulsa$\mathrm{ePKj}$

Abidah, A., Hidaayatullaah, H. N., Simamora, R. M., Fehabutar, D., \& Mutakinati, L. (2020). The Impact of Covid-19 to Indonesian Education and Its Relation to the Philosophy of "Merdeka Belajar." Studies in Philosophy of Science and Education, 1(1), 38-49. https://doi.org/10.46627/sipose.v1i1.9

Alifia, U., Barasa, A. R., Bima, L., Pramana, R. P., Revina, S., \& Tresnatri, F. A. (2020). Belajar dari Rumah: Potret Ketimpangan Pembelajaran pada Masa Pandemi COVID-19. Smeru Institute, $1, \quad 1-8$. http://www.smeru.or.id/sites/default/files/publication/cp01_covidpjj_in_0.pdf

Aswat, H., Sari, E. R., Aprilia, R., Fadli, A., \& Milda, M. (2021). Implikasi Distance Learning di Masa Pandemi COVID 19 terhadap Kecerdasan Emosional Anak di Sekolah Dasar. Jurnal Basicedu, 5(2), 761-771. https://doi.org/10.31004/basicedu.v5i2.803

Azevedo, J. P., Hasan, A., Goldemberg, D., Geven, K., \& Iqbal, S. A. (2021). SIMULATING THE POTENTIAL IMPACTS OF COVID-19 SCHOOL CLOSURES ON SCHOOLING AND LEARNING OUTCOMES: A SET OF GLOBAL ESTIMATES. The World Bank Research Observer, 36(1), 46. https://doi.org/10.1093/wbro/lkab003

Banerjee, P. A. (2016). A systematic review of factors linked to poor academic performance of disadvantaged students in science and maths in schools. Cogent Education, 3(1), 1178441. https://doi.org/10.1080/2331186X.2016.1178441

Beatty, A., Berkhout, E., Bima, L., Pradhan, M., \& Suryadarma, D. (2021). Schooling progress, learning reversal: Indonesia's learning profiles between 2000 and 2014. International Journal of Educational Development, 102436. https://doi.org/10.1016/j.ijedudev.2021.102436

Boudreau, E. (2020). Bridging the Gaps. Harvard Graduate School of Education. https://www.gse.harvard.edu/news/uk/20/05/bridging-gaps

Chen, L.-K., Dorn, E., Sarakatsannis, J., \& Wiesinger, A. (2021). Teacher survey : Learning loss is global and significant. McKinsey \& Company, March. https://www.mckinsey.com/ /media/McKinsey/Industries/Public and Social Sector/Our Insights/Teacher survey Learning loss is global and significant/Teacher-survey-Learningloss-is-global-and-significant.pdf?shouldIndex=false

Chowdhury, A. Z., \& Jomo, K. S. (2020). Responding to the COVID-19 Pandemic in Developing Countries: Lessons from Selected Countries of the Global South. Development, 63(2-4), 162-171. https://doi.org/10.1057/s41301-020-00256-y

Creswell, J. W. (2018). Penelitian Kualitatif Dan Desain Riset Memilih Di Antara Lima Pendekatan (3rd ed.). Pustaka Pelajar.

Cummiskey, C., Stern, J., DeStefano, J., \& Piper, B. (2020). CALCULATING THE EDUCATIONAL IMPACT OF COVID-19 (PART II): USING DATA FROM SUCCESSIVE GRADES TO ESTIMATE LEARNING LOSS. The Education and Development Forum 
(UKFIET). https://www.ukfiet.org/2020/calculating-the-educational-impact-of-covid-19part-ii-using-data-from-successive-grades-to-estimate-learning-loss/

Day, T., Chang, I.-C. C., Chung, C. K. L., Doolittle, W. E., Housel, J., \& McDaniel, P. N. (2021). The Immediate Impact of COVID-19 on Postsecondary Teaching and Learning. The Professional Geographer, 73(1), 1-13. https://doi.org/10.1080/00330124.2020.1823864

Direktorat Guru dan Tenaga Kependidikan Pendidikan Dasar Kemendikbud Ristek. (2021). Agar Terhindar Dari Learning Loss, Sekolah Wajib Berikan Opsi Belajar Tatap Muka Terbatas. Pgdikdas.Kemdikbud.Go.Id. http://pgdikdas.kemdikbud.go.id/read-news/agar-terhindardari-learning-loss-sekolah-wajib-berikan-opsi-belajar-tatap-muka-terbatas

Djalante, R., Lassa, J., Setiamarga, D., Sudjatma, A., Indrawan, M., Haryanto, B., Mahfud, C., Sinapoy, M. S., Djalante, S., Rafliana, I., Gunawan, L. A., Surtiari, G. A. K., \& Warsilah, H. (2020). Review and analysis of current responses to COVID-19 in Indonesia: Period of January to March 2020. Progress in Disaster Science, 6, 100091. https://doi.org/10.1016/j.pdisas.2020.100091

Gershenson, S., \& Hayes, M. S. (2017). The Summer Learning of Exceptional Students. American Journal of Education, 123(3), 447-473. https://doi.org/10.1086/691226

Hakami, Z., Vishwanathaiah, S., Abuzinadah, S. H., Alhaddad, A. J., Bokhari, A. M., Marghalani, H. Y. A., \& Shahin, S. Y. (2021). Effects of COVID-19 lockdown on the mental health of dental students: A longitudinal study. Journal of Dental Education, July, jdd.12758. https://doi.org/10.1002/jdd.12758

Hanushek, E. A., \& Woessmann, L. (2020). The Economic Impacts of Learning Losses. OECD Education Working Papers, 225(September), 6-24. https://doi.org/https://doi.org/10.1787/19939019

Hares, S., \& Mundy, K. (2020). EQUITY-FOCUSED APPROACHES TO LEARNING LOSS DURING COVID-19. The Education and Development Forum (UKFIET). https://www.ukfiet.org/2020/equity-focused-approaches-to-learning-loss-during-covid-19/

Hasudungan, A. N. (2021). Muslim and Christian Relations in The Field of Education After The Ambon-Maluku Conflict ( The Biggest Religious Conflict in Indonesia ). Journal of Education, Society \& Multiculturalism, 1(3), 40-54. https://www.jesm.ro/wpcontent/uploads/2021/08/Articol-3JESM-iunie-indonezian-1.pdf

Hasudungan, A. N., \& Kurniawan, Y. (2018). Meningkatkan Kesadaran Generasi Emas Indonesia Dalam Menghadapi Era Revolusi Industri 4.0 Melalui Inovasi Digital Platform www.indonesia2045.org (A. Sifaunajah (ed.); Vol. 1, pp. 51-58). SNAMI: Prosiding Seminar Nasional Multidisiplin KH. A. Wahab Hasullah University Jombang. https://ejournal.unwaha.ac.id/index.php/snami/article/view/263

Heyward, M., \& Sopantini. (2013). Education in South-East Asia. In L. P. Symaco (Ed.), Bloomsbury Academic (p. 173). Bloomsbury Publishing Plc. https://doi.org/10.15730/books.7

Kaffenberger, M. (2021). Modelling the long-run learning impact of the Covid-19 learning shock: Actions to (more than) mitigate loss. International Journal of Educational Development, 81(December 2020), 102326. https://doi.org/10.1016/j.ijedudev.2020.102326 
Kasih, A. P. (2020). Kemendikbud Anggarkan Rp 7,2 T Sediakan Kuota untuk Siswa dan Guru. Kompas.Com. https://www.kompas.com/edu/read/2020/08/28/064440671/kemendikbudanggarkan-rp-72-t-sediakan-kuota-untuk-siswa-dan-guru

Kisno, Calen, Tampubolon, M. R., Manalu, T. S., Berlien, R., Gulo, K. N., \& Kešner, A. (2021). Teachers' Learning Loss Diminution Through Self-Phased Learning with Guru Binar. Indonesian Journal of Educational Studies, 24(1), 17-26. https://doi.org/https://doi.org/10.26858/ijes.v24i1.19473

Kuhfeld, M., Soland, J., Tarasawa, B., Johnson, A., Ruzek, E., \& Liu, J. (2020). Projecting the Potential Impact of COVID-19 School Closures on Academic Achievement. Educational Researcher, 49(8), 549-565. https://doi.org/10.3102/0013189X20965918

Kurniawan, H., \& Budiyono, B. (2021). Heroe's model: Case study to reduce students' learning loss and anxiety. Cypriot Journal of Educational Sciences, 16(3), 1122-1140. https://doi.org/10.18844/cjes.v16i3.5830

Mabruroh, I. W. (2021). Naiknya Angka Putus Sekolah dan Pernikahan Anak Kala Pandemi. Www.Republika.Co.Id. https://www.republika.co.id/berita/qonx38409/naiknya-angkaputus-sekolah-dan-pernikahan-anak-kala-pandemi

Miles, M. B., \& Huberman, A. M. (1994). Qualitative Data Analysis: An Expanded Sourcebook, 2nd Edition (2nd ed.). Sage Publications.

Muslim, A. B. (2021). Disadvantaged but more resilient: the educational experiences of indigenous Baduy children of Indonesia. Diaspora, Indigenous, and Minority Education, 15(2), 99-112. https://doi.org/10.1080/15595692.2020.1839408

Muttaqin, T., Wittek, R., Heyse, L., \& Van Duijn, M. (2017). Why Do Children Stay Out Of School In Indonesia? Jurnal Perencanaan Pembangunan: The Indonesian Journal of Development Planning, 1(2), 93-108. https://doi.org/10.36574/jpp.v1i2.12

Pokhrel, S., \& Chhetri, R. (2021). A Literature Review on Impact of COVID-19 Pandemic on Teaching and Learning. Higher Education for the Future, 8(1), 133-141. https://doi.org/10.1177/2347631120983481

Primasari, I. F. N. D., \& Zulela. (2021). Kendala Pembelajaran Jarak Jauh (PJJ) Secara Online Selama Masa Pandemik Covid-19 di Sekolah Dasar. JIKAP PGSD: Jurnal Ilmiah Ilmu Kependidikan, 5(1), 64-73. https://doi.org/https://doi.org/10.26858/jkp.v5i1.16820

Purnamasari, N., Heru, A., \& Herawati, F. (2021). Implementation of Distance Learning and Assessment in Kindergarten in Emergency Circumtances. Indonesian Journal of Educational Assessment, 3(2). https://doi.org/10.26499/ijea.v3i2.76

Putra, P., Liriwati, F. Y., Tahrim, T., Syafrudin, S., \& Aslan, A. (2020). The Students Learning from Home Experiences during Covid-19 School Closures Policy In Indonesia. Jurnal Iqra' : Kajian Ilmu Pendidikan, 5(2), 30-42. https://doi.org/10.25217/ji.v5i2.1019

Sabates, R., Carter, E., \& Stern, J. M. B. (2021). Using educational transitions to estimate learning loss due to COVID-19 school closures: The case of Complementary Basic Education in Ghana. International Journal of Educational Development, 82(June 2020), 102377. https://doi.org/10.1016/j.ijedudev.2021.102377

Sparrow, R., Dartanto, T., \& Hartwig, R. (2020). Indonesia Under the New Normal: Challenges 
and the Way Ahead. Bulletin of Indonesian Economic Studies, 56(3), 269-299. https://doi.org/10.1080/00074918.2020.1854079

UNESCO, UNICEF, World Bank, \& OECD. (2021). 1 in 3 countries are not taking action to help students catch up on their learning post-COVID-19 school closures. Unicef.Org. https://www.unicef.org/press-releases/1-3-countries-are-not-taking-action-help-studentscatch-their-learning-post-covid-19

United Nations. (2020). Policy Brief: The Impact of COVID-19 on the Arab Region: An Opportunity to Build Back Better. In United Nations. https://www.unescwa.org/sites/www.unescwa.org/files/sg_policy_brief_covid19_and_arab_states_english_version_july_2020.pdf\%0Ahttps://unsdg.un.org/resources/poli cy-brief-impact-covid-19-arab-region-opportunity-build-back-better

Wagner, E., \& Warren, H. (2020). Save Our Education. Save the Children International. https://resourcecentre.savethechildren.net/node/17871/pdf/save_our_education_0.pdf

Widyanuratikah, I. (2021). PGRI: Kolaborasi Dibutuhkan untuk Minimalkan Learning Loss. Republika.Co.Id. https://www.republika.co.id/berita/qnc86f284/pgri-kolaborasi-dibutuhkanuntuk-minimalkan-emlearning-lossem

Williams, J. M., Greenleaf, A. T., Barnes, E. F., \& Scott, T. R. (2019). High-achieving, lowincome students' perspectives of how schools can promote the academic achievement of students living in poverty. Improving Schools, 22(3), 224-236. https://doi.org/10.1177/1365480218821501

Yarrow, N., Masood, E., \& Afkar, R. (2020). Estimates of COVID-19 Impacts on Learning and Earning in Indonesia. In Estimates of COVID-19 Impacts on Learning and Earning in Indonesia (Issue August). World Bank, Washington, DC. https://doi.org/10.1596/34378

Yulia, Y. (2013). TEACHING CHALLENGES IN INDONESIA: MOTIVATING STUDENTS AND TEACHERS' CLASSROOM LANGUAGE. Indonesian Journal of Applied Linguistics, 3(1), 1. https://doi.org/10.17509/ijal.v3i1.186

Zhao, Y. (2021). Build back better: Avoid the learning loss trap. PROSPECTS, 0123456789. https://doi.org/10.1007/s11125-021-09544-y 